\title{
La violencia como espectáculo. Un deseo ardiente, un placer secreto
}

\author{
y un delicioso escalofrío
}

\author{
Violence as spectacle. A burning desire, a secret pleasure \\ and a delicious shiver \\ Juan Carlos Pérez Jiménez \\ Universidad Complutense de Madrid
}

\begin{abstract}
Resumen
La violencia en los medios de comunicación y en el imaginario social, como una constante histórica, ha encontrado su máxima expresión a través de la multiplicación de pantallas. La relación con el Otro y la forja de la identidad propia a través de la agresión y la violencia. Con Hannah Arendt, Susan Sontag y las ideas de Freud y Lacan como referentes en esta reflexión.
\end{abstract}

Palabras clave: Violencia, medios de comunicación, psicoanálisis, Arendt, Sontag.

\begin{abstract}
Violence in mass media and the social imaginary, as an historical constant, has reached its peak through the multiplication of personal screens. The link with the Other and the making of our own identities through aggression and violence. Hannah Arendt, Susan Sontag and the ideas of Freud and Lacan are the main references of this essay.
\end{abstract}

Key words: Violence, mass media, psychoanalysis, Arendt, Sontag.

Recibido: 24-9-17. Aceptado: 13-12-17

Juan C. Pérez es Director de Imagen, PRISA, y Doctor en Ciencias de la Información.

Contacto: Juan C. Pérez, C/ Juan de la Hoz 3 bis, 28028, Madrid jcpj00@gmail.com

Cómo citar: Pérez, J. C. (2018). La violencia como espectáculo. Un deseo ardiente, un placer secreto y un delicioso escalofrío. Revista Stultifera, 1 (1), 13-29. ISSN 0719-983X

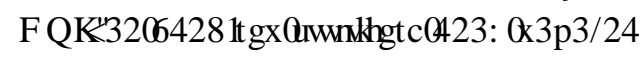




\section{LA VIOLENCIA COMO ESPECTÁCULO}

Con la violencia nos olvidamos de quienes somos Mary McCarthy ${ }^{1}$

Harold Bloom atribuyó, no sin razón, a Shakespeare nada menos que la invención de lo humano, quizás porque en su obra recoge todo el catálogo de pasiones, miserias, virtudes y desventuras que atañen a nuestra existencia mortal. Pero antes de Shakespeare, los griegos ya pensaron en todo lo que es susceptible de ser pensado. A ellos recurro para empezar esta reflexión, y después serán dos mujeres, Hannah Arendt y Susan Sontag, las que nos acompañen en este recorrido por la idea de la violencia como espectáculo.

En un pasaje del Libro Cuarto de La República, Platón pone en boca de Sócrates una historia que oyó sobre Leoncio, hijo de Aglayón:

Subía del Pireo por la parte exterior de la muralla norte cuando advirtió tres cadáveres que estaban echados por tierra al lado del verdugo. Comenzó entonces a sentir deseos de verlos, pero al mismo tiempo le repugnaba y se retraía; y así estuvo luchando y cubriéndose el rostro hasta que, vencido de su apetencia, abrió enteramente los ojos y, corriendo hacia los muertos, dijo: “¡Ahí los tenéis, malditos, saciaos del hermoso espectáculo!”. (Sontag, 2003, capítulo 6 , párrafo 3)

"Platón [nos recuerda Susan Sontag al recuperar este pasaje en su libro Ante el dolor de los demás] parece dar por sentado que también sentimos apetencia por contemplar la degradación, el dolor y la mutilación" (Sontag, 2003, capítulo 6, párrafo 4). La violencia, el despliegue de lo abyecto, proyecta un espectáculo que nos convoca, un espectáculo capaz de fascinar, que nos coloca en un extraño lugar, entre el sadismo y el masoquismo, el lugar de un goce oscuro que nos lleva a preguntarnos de dónde proviene su fuerza de atracción.

La contemplación de la violencia se puede entender como un ejercicio de alienación voluntaria, que nos hace olvidarnos de quienes somos, como dice McCarthy. Se trata de un ejercicio doblemente letal y alienante. En primer lugar, porque el dolor y la destrucción de los demás siempre reafirman la propia integridad, la propia vida, atesoradas inoportunamente cuando el que sufre o el que muere es otro. En segundo lugar, porque la presencia de la muerte nos separa de la memoria, del quiénes somos para instalarnos ante un interrogante sin respuesta, como explica la etimología de letal, que toma su nombre del río Leteo, el río del 


\section{JUAN CARLOS PÉREZ JIMÉNEZ}

olvido enajenante que llevaba hasta el Hades, el lugar de los muertos y condenados. Y ese doble ejercicio de muerte y enajenación nos deleita, en cierto modo.

El término violencia deriva de vis, fuerza, y lentus, partícula temporal que remite a la idea de continuidad; así pues, el que continuamente usa la fuerza es el violento. Vigor, virilidad y virtud comparten con la palabra violencia la misma raíz. Un linaje noble, pues, el de este significante, estrechamente ligado etimológica y genealógicamente al universo de lo fálico. Por eso, cuando Hannah Arendt afirma en su certera reflexión sobre este concepto, titulada On Violence, que "la violencia no es otra cosa que la más flagrante manifestación de poder"(Arendt, 1970, capítulo 2, párrafo 1), nos ayuda a entender el espectáculo de la violencia como un despliegue de la potencia fálica, de la posición masculina, razón por la cual no suele tener el mismo efecto ni implicar de igual modo a quienes se sitúan en un lugar que orbite exclusiva o parcialmente sobre la posición femenina.

Desde esa perspectiva del goce fálico se entiende la afirmación del romano Juvenal, recogida por Arendt, cuando dice que "un hombre se siente más hombre cuando se impone y convierte a los otros en instrumentos de su voluntad" (Arendt, 1970, capítulo 2, párrafo 2) lo que le procura "un placer incomparable" (Arendt, 1970, capítulo 2, párrafo 2). O, como dice Voltaire, la violencia "consiste en hacer que los otros actúen como yo decido" (Arendt, 1970, capítulo 2, párrafo 2) y está presente siempre que yo tenga la ocasión de "afirmar mi propia voluntad contra la resistencia de otros" (Arendt, 1970, capítulo 2, párrafo 2), tal como afirma Max Weber. En esta misma línea de definición de la violencia como un ejercicio de poder y sumisión, los comisarios de una reciente exposición que tuvo lugar en el Museo de Arte Moderno de Nueva York, en torno a la presencia de la violencia en lo social a través del diseño, delimitaban el concepto afirmando que "la violencia es una manifestación del poder para alterar las circunstancias que nos rodean, contra la voluntad de otros y en su detrimento" (Antonelli y Hunt, 2015, p.10).

Cuando nos preguntamos si vivimos una época particularmente violenta, algunos documentan un declinar de las prácticas sociales más crueles y sanguinarias, como las ejecuciones y castigos públicos de otras épocas. En términos relativos o en lo que se refiere a la exposición en primer grado al acto violento, puede que haya habido un descenso, pero sin duda ha aumentado en términos absolutos y se ha disparado la contemplación de la 


\section{LA VIOLENCIA COMO ESPECTÁCULO}

violencia diferida que recogen los medios audiovisuales, ya sea en su versión real e informativa o en las recreaciones virtuales de la ficción. Ya no presenciamos decapitaciones en la plaza pública, pero las visionamos en YouTube. Los niños ya no se dedican a torturar y matar animales domésticos, ahora disparan y destruyen alienígenas y zombies a un promedio de 500 al día. Y los adultos nos hemos acostumbrado a cenar enfrentados a una pantalla repleta de víctimas reales de guerras, accidentes y atentados, para luego tomarnos el postre viendo series en las ya que no sobrevive ni el protagonista.

\section{Pulsión de muerte}

Tras la terrible vivencia de la I Guerra Mundial, Freud escribe su Más allá del principio del placer (1920), texto en el que atribuye al concepto de pulsión de muerte tanto peso como al principio del placer. Tras una década elaborando la idea, en El malestar en la cultura (1930), afirma que:

La verdad oculta tras de todo esto, que negaríamos de buen grado, es la de que el hombre no es una criatura tierna y necesitada de amor, que solo osaría defenderse si se lo atacara, sino por el contrario, un ser entre cuyas disposiciones instintivas también debe incluirse una buena porción de agresividad. Por consiguiente, el prójimo no le representa únicamente un posible colaborador y objeto sexual, sino también un motivo de tentación para satisfacer en él su agresividad, para explotar su capacidad de trabajo sin retribuirla, para aprovecharlo sexualmente sin su consentimiento, para apoderarse de sus bienes, para humillarlo, para ocasionarle sufrimientos, martirizarlo y matarlo. (Freud, 1987a, p. 3.020)

En el intercambio epistolar que tuvo lugar en 1932 entre Albert Einstein y Sigmund Freud conocido como “¿Por qué la guerra?” (Freud, 1987b), Einstein, en su interpelación a Freud para encontrar una respuesta a la gran pregunta que le inquietaba, ya se daba a sí mismo la respuesta cuando escribía que "el hombre tiene dentro de sí un apetito de odio y destrucción" (Freud, 1987b, p. 3208). Unos meses más tarde, Freud le responde con una larga y profunda carta en la que afirma que:

Los conflictos de intereses entre los hombres se zanjan en principio mediante la violencia. Así es en todo el reino animal, del que el hombre no debiera excluirse; en su caso se suman todavía conflictos de opiniones, que alcanzan hasta el máximo grado de la abstracción y parecen requerir de otra técnica para resolverse. Pero esa es una complicación tardía. Al comienzo, en una pequeña horda de seres humanos, era la fuerza muscular la que decidía a quién pertenecía algo o de quién debía hacerse la voluntad. La fuerza muscular se vio pronto aumentada y sustituida por el uso de instrumentos: vence quien tiene las mejores armas o las 


\section{JUAN CARLOS PÉREZ JIMÉNEZ}

emplea con más destreza. Al introducirse las armas, ya la superioridad mental empieza a ocupar el lugar de la fuerza muscular bruta; el propósito último de la lucha sigue siendo el mismo: una de las partes, por el daño que reciba o por la paralización de sus fuerzas, será constreñida a deponer su reclamo o su antagonismo. Ello se conseguirá de la manera más radical cuando la violencia elimine duraderamente al contrincante, o sea, cuando lo mate. (Freud, 1987b, p. 3208)

Y continúa diciendo Freud a Einstein:

Las pulsiones del ser humano son solo de dos clases: aquellas que quieren conservar y reunir - las llamamos eróticas, exactamente en el sentido de Eros en El banquete de Platón, o sexuales, con una consciente ampliación del concepto popular de sexualidad-, y otras que quieren destruir y matar; a estas últimas las reunimos bajo el título de pulsión de agresión o de destrucción. Como usted ve, no es sino la trasfiguración teórica de la universalmente conocida oposición entre amor y odio; esta quizá mantenga un nexo primordial con la polaridad entre atracción y repulsión, que desempeña un papel en la disciplina de usted. Ahora permítame que no introduzca demasiado rápido las valoraciones del bien y el mal. Cada una de estas pulsiones es tan indispensable como la otra; de las acciones conjugadas y contrarias de ambas surgen los fenómenos de la vida. (Freud, 1987b, p. 3210)

Lo que resulta más revelador, algo que conecta con la infinitamente inquietante idea lacaniana de goce, es esta última frase de Freud, que matiza el prejuicio moral hacia la disposición instintiva - pulsional, deberíamos decir- a la agresividad a la que él mismo hace referencia en El malestar en la cultura, y que se complementa con la reflexión que Hannah Arendt hace en su texto Sobre la violencia, cuando afirma lo siguiente:

Si tenemos que confiar en nuestra propia experiencia sobre la cuestión, deberíamos saber que el instinto de sumisión, el deseo ardiente de obedecer y de ser gobernado por un hombre fuerte, es al menos tan prominente en la psicología humana como el deseo de poder, $y$, políticamente, quizás más relevante. (Arendt, 1970, capítulo 2, párrafo 4)

Lo dice Hannah Arendt en ese texto de 1970, Sobre la violencia, basándose en una experiencia sobre la cuestión que se nutre de su propio disgusto cuando presentó en Eichmann en Jerusalén (1961) el Holocausto desde perspectivas poco convencionales, con la consiguiente polémica tras el rechazo de muchos sectores, incluidos los judíos, por su abordaje de la condición humana ante la administración organizada del horror, recogido en el concepto de la banalidad del mal, y también por su señalamiento de colaboracionismo a responsables de los Consejos judíos. Su experiencia sobre la cuestión también pasa por ser la autora de una obra clave de la filosofía política del siglo XX, nada menos que Los orígenes 


\section{LA VIOLENCIA COMO ESPECTÁCULO}

del totalitarismo $(1951)^{2}$. Y aunque Arendt no remite explícitamente en su texto sobre la violencia al Holocausto, afirma que sin ese deseo ardiente de ser sometidos que brota en el sujeto "la vieja institución de la economía esclavista se haría inexplicable" (Arendt, 1970, capítulo 2, párrafo 4) y se deduce que probablemente otros pasajes del horror de la historia humana habrían encontrado mayor resistencia sin la connivencia de esa pulsión. Muy en la línea freudiana, en su reflexión sobre el equilibrio paradójico y complementario entre violencia y vida, Arendt se pregunta: “ ¿No han identificado los hombres la muerte siempre con 'el descanso eterno' y no se concluye que donde hay vida hay siempre lucha y desasosiego?" (Arendt, 1970, capítulo 3, párrafo 11).

\section{La paradoja del bombero pirómano}

Jacques Lacan nos recuerda en “¿Qué es un cuadro?” en el Seminario 11, que la obra de arte procura "sosiego al deseo de contemplar" (Lacan, 2010, p. 118) y reconforta al "ojo desesperado por la mirada" (Lacan, 2010, p. 123). Pero, en el extremo opuesto, el espectáculo de los mass media o de los social media enerva y dispara el deseo de contemplar en una espiral sin fin, añadiendo más desesperación al ojo. La envidia, por ejemplo, es uno de los efectos perversos de la mirada. Así es como Facebook se convierte en una gran fábrica de envidias, en expresión de Vicente Serrano (2016). Envidia, del latín in (poner sobre, ir hacia) videre, poner la mirada sobre algo (mirar con malos ojos, echar mal de ojo, heredan la connotación de hacer mal con la mirada). Envidia, mal del ojo... La lista de esos efectos perversos universales de la pulsión escópica es larga. Pero no parece que de la mirada se puedan derivar efectos benéficos; solo riesgos y abismo: "En ninguna parte hay la menor huella de un buen ojo, de un ojo que bendice. ¿Qué significa esto, si no que el ojo entraña la función mortal de estar dotado de por sí [...] de un poder separador?” (Lacan, 2010, p. 122).

Los ojos funcionan como frontera con el antagonista, con el rival, con el Otro, y con el mundo (la frontera entre el Innenwelt y el Umwelt, que dice Lacan en "El estadio del espejo") (Lacan, 2013, p. 102), con los que solo se tiende un puente sosegante si hay arte, si hay poesía y elaboración en la mirada.

La relación de los medios de comunicación con la violencia es tan compleja como problemática, en particular cuando el espectáculo no se alimenta de violencia de ficción, sino 


\section{JUAN CARLOS PÉREZ JIMÉNEZ}

de catástrofes, accidentes, atentados y guerras, de violencia y muerte reales. La información audiovisual sobre estos asuntos, que en principio debería tener un enfoque de prevención o denuncia, se convierte con frecuencia en lo contrario, en la propagación reiterada de inseguridad, morbo y miedo que conecta con facilidad con los puntos débiles de una audiencia ávida de reafirmaciones. El espectador espera su dosis de violencia visual para reforzar su postura defensiva (separadora o paranoica) ante una sociedad que percibe como agresiva y hostil. Y en lugar de atemperar la fuente de los temores mediante las claves que podría facilitar, la manguera informativa riega de combustible las brasas del miedo y la agresividad. Y es que se puede decir que los medios de comunicación tienen el semblante de un bombero pirómano, que sabe bien que su misión es apagar el fuego y que cumple con su deber. Solo que cuando todo ha quedado en orden, no puede evitar arrojar una cerilla para volver a participar en el espectáculo que tanto le fascina. Una mecánica que lejos de provocar aversión a la información, genera una dependencia maligna de la versión más manipuladora del periodismo.

Y eso es lo que ha ocurrido con la información masiva en todo el mundo y más aún en un país tan propenso a la paranoia como Estados Unidos. La atracción por el drama y la afición a los sucesos son incontenibles y lo peor es que alimentan un clima que acaba en más de 12.000 asesinatos anuales, otorgando así a aquel país un vergonzante récord mundial. Resulta tentador disfrazar de servicio al público la información más morbosa sobre lo que sucede en nuestro mundo. Con un ademán de preocupación y de interés por el otro, se cubren exhaustivamente los casos más escabrosos, recreándose en detalles que merecerían intimidad y respeto. El visionado acumulativo de estos sucesos alimenta fácilmente la desconfianza hacia los demás, hacia el entorno. La idea de inseguridad corre de boca en boca como prioridad social. Todas y cada una de las conductas perversas y de los actos criminales que tienen lugar en Occidente están descritos al por menor en uno u otro medio. No se puede cerrar los ojos a la realidad, pero no apartar la vista de la llaga no creo que sea realismo. Michael Moore lo recogía con cifras en Bowling for Columbine: aunque los crímenes hayan descendido un $20 \%$ en los últimos años, la información sobre ellos ha aumentado un $600 \%$.

La pulsión escópica, espoleada por Thánatos, es vulnerable al atractivo de la violencia, al espectáculo morboso de un cuerpo roto, que confirma y verifica nuestro carácter 


\section{LA VIOLENCIA COMO ESPECTÁCULO}

mortal. Imposible dejar de mirar cuando hay un accidente, y no es precisamente por altruismo samaritano, como bien dice la cita de Platón que abre este texto. Pero, además, no solo nos recreamos con el espectáculo de la violencia física, también la violencia moral es capaz de provocar esa fascinación mórbida e irresistible. Así nos lo recuerda Dostoievski —otro de los responsables de la invención de lo humano-, cuando pone la siguiente frase en boca de los hermanos Karamazov: El hombre se deleita con la caída del justo y con su oprobio.

Es verdad que la sociedad espectacular no se alimenta solo de Thánatos, sino también de Eros, de la pulsión de vida, en sus versiones más comerciales y degradadas. "La apetencia por las imágenes que muestran cuerpos dolientes es casi tan viva como el deseo por las que muestran cuerpos desnudos" (Sontag, 2003, capítulo 3, párrafo 3). Estamos saturados de producciones audiovisuales que giran en torno al ideal de las relaciones de pareja, de comedias románticas que banalizan el amor y de imágenes pornográficas de sexo crudo, desnudo de todo sentimiento, hasta el punto en que el porno se ha convertido en una insignia de nuestro tiempo. Pero eso sería objeto de otra reflexión.

Se necesitan, pues, medios de comunicación responsables (un oxímoron tan grande como pedir banqueros altruistas) que no abonen la mirada más torva del espectador $\mathrm{y}$, por supuesto, una audiencia madura (o sea, pedimos lo imposible) que se distancie de lo que recibe y lo sitúe en su contexto. En caso contrario, no dejaremos de abonar lo que el analista berlinés Hans Dieckmann, en un artículo en el que reflexionaba sobre la amenaza nuclear, denomina como complejo de Noé, el deseo de borrar la vida de la faz de la tierra y empezar de nuevo, que no es otra cosa, de nuevo, que la pulsión de muerte freudiana, y que según Dieckmann es el resultado del profundo disgusto del ciudadano moderno con su mundo. Y, probablemente, el de todos los sujetos de todas las épocas. La fantasía catastrofista que en algún momento puede hacernos añorar la hecatombe - y que explica el éxito de la ingente producción de ficción en este campo- responde a un desprecio hacia el género humano tal como lo conocemos. El Apocalipsis y el Juicio Final, las predicciones milenaristas, el holocausto nuclear y la catástrofe ecológica, incluido el famoso meteorito, son todas formas de imaginar un final para el mundo que conocemos que quizás también encierren la esperanza de un nuevo comienzo. Dieckmann opina que existe en nosotros un complejo inconsciente que en realidad anhela, con una especie de placer secreto, una guerra aniquiladora y terrible. 


\section{JUAN CARLOS PÉREZ JIMÉNEZ}

Nos hemos erigido en el dios vengador capaz de enviar a la humanidad el diluvio justiciero que acabe con todos los errores y toda la barbarie, exterminando todo rastro de vida. Aunque en la imaginación popular, la historia no acaba con el diluvio. Y siempre hay un pequeño grupo de elegidos que protagoniza, menos mal, el nuevo día. En nuestro contexto cultural judeocristiano, el concepto de redención se asocia de manera inconsciente con la idea del fin del mundo. Ese puede ser el motivo - dice Dieckmann (1985) - por el que, en nuestro fuero interno, el miedo que evocan los horrores del fin del mundo no acabe de tener efecto y no nos influya para trabajar en su prevención.

Ante la previsión de un fin inevitable por saturación y exceso, la perspectiva de la catástrofe casi total supone una paradójica alternativa saneada y enfermiza. Un artículo publicado hace años en el diario francés Libération, a propósito de un accidente en una central atómica, denunciaba el peligro del delicioso escalofrío del riesgo nuclear. El cosquilleo contradictorio que provoca el anuncio de un gran cataclismo - cuando no nos coge cerca - se parece al que se compra con la entrada de una producción audiovisual de ese exitoso género que es el cine de catástrofes. En esa agridulce sensación que se experimenta ante el desastre absoluto, se puede leer un fondo de castigo apocalíptico merecido por las incontables atrocidades, contra nosotros mismos y contra el planeta, que hemos protagonizado ya. Y las que nos quedan si no estalla la bomba o se hunden nuestras ciudades bajo el mar.

La pulsión de agresión o de destrucción, le explica Freud a Einstein, en su intercambio epistolar en torno al por qué de la guerra, "trabaja dentro de todo ser vivo y se afana en producir su descomposición, en reconducir la vida al estado de la materia inanimada. Merecería con toda seriedad el nombre de pulsión de muerte" (Freud, 1987b, p. 3213). Esa atracción mortífera por el fin de la vida actúa en nosotros especialmente cuando lo que está en juego es la muerte del otro, como se ha dicho más arriba, esa muerte ajena que reafirma transitoriamente nuestra propia existencia y que puede combinar sin pudor el gusto por la tragedia con el dolor más profundamente sentido. La violencia, la tragedia y la catástrofe son señuelos a los que resulta difícil resistirse y los responsables de los medios de comunicación lo saben bien: una manera fácil de convocar o retener a la audiencia es contando los dramas de otros. Ya decía Edmund Burke en el siglo XVIII que, si el terror no tiene relación con el 


\section{LA VIOLENCIA COMO ESPECTÁCULO}

peligro real de destrucción de la persona, puede producir deleite. Sontag también recupera a Burke y nos recuerda que nos "advirtió que a la gente le gusta ver imágenes de sufrimiento. 'Estoy convencido de que nos deleitan, en no poca medida, los infortunios y sufrimientos de los demás', escribió en Investigación filosófica sobre el origen de nuestra idea acerca de lo bello y lo sublime (1757)" (Sontag, 2003, capítulo 6, párrafo 6). Cuando escuchamos el relato o visionamos el espectáculo de la destrucción de otro, desde la posición segura del oyente o el espectador, el escalofrío que produce contemplar ese espectáculo se compensa con el sentimiento reconfortante de saberse a salvo. El que muere es otro, no yo. Su vulnerabilidad es la mía, pero esta vez, no ha sido mi vida la que ha acabado. Ese es el deleite del que habla Burke, el deleite de burlar el vuelo de la azada de la muerte, viéndola segar otra vida desde la barrera.

Los umbrales de tolerancia a la imagen de la agresión y la destrucción han llegado hasta extremos aberrantes, hasta alcanzar el componente de excepcionalidad asociado a la ultraviolencia, que ayuda a percibirla como ficción incluso aunque sea real, como algo ajeno a nuestro mundo. Ahora las pantallas muestran sin pudor el cuerpo desarticulado, desmembrado, destruido y la disección de los tejidos más íntimos aparece no solo en los informativos, sino en programas quirúrgicos y series médicas o forenses con afán de mero entretenimiento. Pero la idea de que el visionado de imágenes violentas puede tener una intención edificante solo se ha aplicado en La naranja mecánica de Anthony Burgess, donde se trataba de extirpar la tendencia agresiva del protagonista exponiéndolo a una incesante sucesión de horrores. En este libro es donde Burgess acuña ese término, ultraviolencia, que remite a una cierta estetización o estilización de la violencia, en el sentido que ya hiciera Thomas de Quincey en el siglo XIX en su ensayo satírico El asesinato considerado como una de las Bellas Artes. De Quincey, que también hablaba de que cuando escribía bajo los efectos del opio sentía el oscuro frenesí del horror (the dark frenzy of horror), un goce que está vinculado con el exceso, con el desborde de lo abyecto.

\section{Matando monstruos}

De nuevo, Lacan en un trabajo titulado La agresividad en psicoanálisis, presentado en 1948, nos habla de cómo las intenciones agresivas generan un espectáculo visual imaginario que todos compartimos. "Son las imágenes de castración, de eviración, de 


\section{JUAN CARLOS PÉREZ JIMÉNEZ}

destripamiento, de devoración, de reventamiento del cuerpo, en una palabra, las imagos que personalmente he agrupado bajo la rúbrica que parece ser estructural de imagos del cuerpo fragmentado" (Lacan, 2013, p. 110). La imagen del cuerpo violentado, fragmentado, no es, sin embargo, una construcción que se nos imponga desde fuera.

No hay sino que escuchar la fabulación y los juegos de los niños, aislados o entre ellos, entre dos y cinco años, para saber que arrancar la cabeza y abrir el vientre son temas espontáneos de su imaginación, que la experiencia de la muñeca despanzurrada no hace más que colmar. (Lacan, 2013, p. 110)

En el libro Matando monstruos, Gerard Jones investiga el papel que juegan los relatos y los despliegues lúdicos de agresiones ficticias en el desarrollo infantil, y se pregunta por qué los niños necesitan fantasía, superhéroes y violencia imaginaria. Con su lectura, se puede concluir que el desorbitado negocio del espectáculo violento que explota la industria audiovisual apoya su elefantiásica estructura sobre una pequeña fragilidad infantil. El niño recurre a la violencia imaginaria para gestionar sus miedos, para administrar su impotencia a la hora de controlar las amenazas exteriores desde una posición fálica, es decir, desde el tener o no tener el poder. Menos frecuente en la niña - o en el infante que se va colocando en posición femenina- esa fascinación resulta menos efectiva, al orientar esa gestión del exterior y del Otro desde una posición más centrada en el amor y el cuidado que en el enfrentamiento y la conquista. El artista audiovisual Daniel Canogar afirma que:

La presencia de armas de fuego en el juego infantil —especialmente el del varón— canaliza los instintos agresivos del niño. En la actualidad, son los videojuegos los que se han convertido en los principales descargadores de estos instintos agresivos infantiles y juveniles. Se calcula que un jugador medio comete unos mil doscientos asesinatos simbólicos por hora, cifra que preocupa a los psicólogos, quienes están comenzando a pensar que estos juegos electrónicos pueden llegar a estimular comportamientos agresivos en el niño. (Canogar, 1993, p. 195)

Esta relación de los niños con las pantallas y la violencia articula la tesis que del libro de Gerald Jones. A lo largo de sus casi trescientas páginas Jones ejemplifica de diversas maneras cómo la violencia mediática puede ser útil a la hora de canalizar la agresividad, digerir miedos y entender las manifestaciones de violencia del mundo real. "Casi todas las historias violentas que apasionan a los niños representan poderosas lecciones sobre el valor, la resistencia y el desarrollo personal" (Jones, 2002, p. 258), afirma Jones, centrándose como 


\section{LA VIOLENCIA COMO ESPECTÁCULO}

objeto de estudio en los videojuegos, las series de dibujos como Pokémon y los personajes de cómic. Jones sugiere que, en lugar de causar una conducta agresiva por imitación, el entretenimiento violento proporciona una catarsis, una afirmación demasiado categórica para aceptarla sin más.

Una cuestión colateral a considerar también serán los valores implícitos en los videojuegos y el resto de las producciones audiovisuales violentas dirigidas a los niños. Un estudio ya clásico de la Universidad de León afirmaba que los juegos de ordenador reproducen estereotipos sexistas y responden a un esquema viril distorsionado. El trabajo destacaba que la representación femenina es menor (un 17\% frente a un 64\%, mientras que el resto supongo que serán monstruos o alienígenas de sexo indefinido) y que la mujer siempre aparece sometida y en actitud pasiva. En el 98\% de los juegos analizados se asociaba al hombre con la dureza y a la mujer con la belleza. Y si los videojuegos se basan en una cultura del macho, no menos preocupantes son los estereotipos que representan las muñecas que arrasan entre las niñas de medio mundo. El ideal de la mujer-barbie sigue funcionando a plena potencia.

Otra investigación realizada entre 1.300 niños de la Comunidad de Madrid para determinar el impacto de la violencia televisiva en la infancia concluía que los niños, que pasan unas dos horas y media diaria ante el televisor sin compañía de ningún adulto, perciben la violencia como algo normal. Un 15\% de los niños daba muestras de resultar influenciado por lo visto en la pantalla, bien imitando lo que ven o presentando un efecto de aprendizaje ante la violencia televisiva. La exposición continua a programas violentos produce, definitivamente, un efecto en el niño, que refuerza una conducta o actitud ya existente o que le enseña nuevas formas de comportamiento (García y Ruiz, 2004). Y otra investigación más del IORTV hecha pública en noviembre de 2004 concluía que los niños que ven más informativos en televisión son menos sensibles a la violencia. Jordi Montferrer, de la Universidad de Salamanca, uno de los autores de este estudio, decía que esos niños generan menos ideas violentas, lo que confirma la teoría de la insensibilización hacia ella. Cuanta más violencia se consume, más nos acostumbramos a ella y menos nos importa ${ }^{3}$. Y aunque es muy probable también que los videojuegos ayuden a los niños a canalizar la violencia, seguro que también es una cuestión de grado y que son mucho mejores para ese objetivo los 


\section{JUAN CARLOS PÉREZ JIMÉNEZ}

juegos que ayudan a descargar la agresividad incluyendo el ejercicio del cuerpo, máxime a una edad en la que la energía desborda y se necesita la interacción con otros niños. Pero ahí los tenemos, pegados a las pantallas, enmudecidos frente a sus consolas, autogestionando su agresividad y matando a solas todo tipo de monstruos. Para averiguar si están venciendo sus temores o si es la partida la que les gana, no habrá más remedio que hablar con ellos. A través de los relatos de fantasía imaginaria, ilustrados con toda profusión de detalles y en todas sus versiones en las ubicuas pantallas, se produce una sublimación de la violencia que se verifica al ejercitarla de manera virtual, lo cual tiene un efecto catártico, como ya dijera Aristóteles, pero también peligrosamente narcótico y adictivo.

\section{La violencia, demasiado humana}

En su reflexión sobre la legitimidad de la violencia Arendt nos alerta de que:

Tenemos que decidir si y en qué medida el 'poder' se puede diferenciar de la 'fuerza', cerciorarnos de cómo el hecho de usar la fuerza según la ley modifica la cualidad de la fuerza misma y nos coloca ante un escenario de las relaciones humanas completamente diferente, dado que la fuerza, por el mero hecho de estar cualificada, deja de ser fuerza. (Arendt, 1970, capítulo 2, párrafo 2)

Es en la declinación de estas sutilezas donde reside la atracción del espectáculo violento. En la lucha entre dos poderes, no solo es relevante quién vence y quién es derrotado, sino que ese despliegue queda entrelazado con la ética de la auctoritas, la fuerza autorizada frente a la fuerza sin más. Frente a esa dilucidación, persiste un modelo de mucho éxito en los medios, el esquema maniqueo ${ }^{4}$, donde el uso de la fuerza por parte del bando autorizado éticamente permite el ejercicio de la violencia sin que exista conflicto moral.

Al recorrer estos conceptos, comprobamos que la lógica civilizatoria es una lógica fálica, un tablero de juego en el que la dominación y la violencia son las reglas básicas. La conquista del mundo y la expansión de los poderes hegemónicos se articulan en torno a unos equilibrios en los que la violencia es la palanca que decide de qué lado se inclina la balanza. Continuando con Arendt, nos fijamos en la siguiente cita, rescatada de los escritos de Paul Valéry: "Se puede decir que todo lo que sabemos, es decir, todo lo que podemos, termina por ponerse en contra de lo que somos" (Arendt, 1997, capítulo 3, párrafo 28). Aquí se podría hablar del precio apocalíptico de la civilización, de lo que abandonamos para entrar en la 


\section{LA VIOLENCIA COMO ESPECTÁCULO}

cultura y en la lógica fálica, una lógica en la que el tener y el poder fagocitan al ser. Porque, en contra de lo que afirmaba Freud en “¿Por qué la guerra?” la violencia humana no es una extensión de las prácticas del reino animal. Eso es la agresividad. Pero la violencia, en tanto que supone una dimensión política, es el resultado de la entrada en la cultura.

Si se entiende la cultura como entrada en la norma, como sumisión del sujeto/súbdito (sujet), se puede concebir la cultura como masoquismo puesto en práctica, que dice Peter Sloterdijk $\mathrm{k}^{5} \mathrm{y}$, por tanto, como un detonante natural para la emergencia de la violencia. Nuestra inscripción en el registro simbólico es violenta por cuanto nos es impuesta. En ese sentido la violencia es estructural y no es erradicable. Entrar en la cultura supone un forzamiento. Desde el control de los esfínteres, a la regulación del hambre y la dieta, desde la limitación del género a la castración edípica, desde la ortopedia del lenguaje a la Ley del Padre (o Ley de la Palabra, como la llama Recalcati, de manera menos heteropatriarcal), todo se inscribe en un registro disciplinario en el que el límite y la regla lindan con el ejercicio de la imposición forzada. Junto con el amor y la ética del cuidado, la sombra de la violencia está siempre planeando sobre el escenario del paso a la cultura y la entrada en el lenguaje.

"Ni la violencia ni el poder son fenómenos naturales [afirma Arendt] es decir, no son manifestaciones del proceso vital; pertenecen al ámbito político de los asuntos humanos" (Arendt, 1970, capítulo 3, párrafo 22). La violencia no es natural, es cultural y política, es un asunto del sujeto. La naturaleza no es violenta, es agresiva, solo vive, sobrevive o muere. Pero no hay en ella una voluntad de poder. La violencia es muy humana, por eso es difícil encontrar entre los animales actos de carácter tan extremo y cruel como los que un hombre puede llegar a desplegar.

En este equilibrio de poder e impotencia:

Sabemos, o deberíamos saber, que toda disminución de poder es una invitación abierta a la violencia -en la medida en que los que detentan el poder, cuando sienten que se les escapa entre los dedos, ya sean gobernantes o gobernados, siempre han encontrado difícil resistirse a la tentación de sustituirlo por violencia. (Arendt, 1970, capítulo 3, párrafo 29)

También tengamos en cuenta que la dialéctica hegeliana del amo y el esclavo es una dialéctica de la violencia y se relaciona con la visión que expone Arendt del deseo ardiente 


\section{JUAN CARLOS PÉREZ JIMÉNEZ}

de ser dominado, de ser sometido, con el ejercicio del poder sobre el otro y con el discurso del amo como discurso coercitivo.

¿Cuál es, en definitiva, nuestra responsabilidad como sujetos ante este panorama? La versión espectacular o imaginaria de la violencia no exime de responsabilidades al sujeto, porque si para la ley solo es relevante lo que se hace, para el psicoanálisis es relevante lo que se hace, lo que se piensa y hasta lo que se sueña. El sujeto es responsable. Así que también lo es de lo que decide ver en una pantalla. La mirada no es inocente, el voyeur forma parte de la escena, hasta el punto que el visionado de determinados contenidos puede llegar a ser ilegal y punible no ya para el psicoanálisis, sino para el derecho penal. No hace falta participar del acto violento. Solo ver, mirar, ciertas escenas de violencia extrema puede ser un acto constitutivo de delito.

En un entorno urbano, el cuerpo de una persona inconsciente tendida en medio de la calle es altamente susceptible de ser ignorado por los transeúntes que, multiplicados, diluyen la responsabilidad de socorro a niveles imperceptibles, como en un medicamento homeopático, hasta llegar al sinsentido, a lo inhumano, frente a la respuesta que esa misma situación provocaría en otro contexto, incluso entre las mismas personas. Conviene preguntarse si cuando el acto violento se convierte en parte del paisaje, los sentimientos se moderan y la compasión se volatiliza. Y en la misma línea, ¿la violencia estilizada puede llevar a un aplanamiento de los afectos, a una insensibilización frente al sufrimiento ajeno, a disfrutar del escalofrío del riesgo, el peligro y el dolor de otros en el contexto de un entorno aséptico y seguro para nosotros?

La fascinación por los cuerpos torturados por el gore que expone prácticas cada vez más extremas a ojos cada vez más jóvenes, podría acabar por matar el nervio óptico de la compasión, al menos de una parte de los espectadores, por insensibilizarnos ante el sufrimiento ajeno. Así, proliferan los vídeos de agresiones reales entre adolescentes, grabados con impunidad, casi con la inconsciencia de que pueda haber algo reprobable en ellos. Si no es nada comparado con la película que acaban de ver. Así se multiplican los ataques de lobos solitarios, jóvenes terroristas de rasgos psicóticos, como los sucedidos estos años en Munich o Florida. Incluso la autoagresión, los cortes y el suicidio, con su prevalencia 


\section{LA VIOLENCIA COMO ESPECTÁCULO}

creciente entre los adolescentes, evidencian que la familiaridad con la violencia contribuye a derribar los muros de contención que deberían refrenar la pulsión de muerte.

Como ya hiciera Freud con respecto a la valoración ética de la pulsión de muerte, Arendt concluye que no se puede desterrar la violencia del catálogo de emociones humanas legítimas, pero que su manejo requiere un complejo ejercicio de voluntad: "No pretendo equiparar la violencia con el mal; para entenderla por lo que es, tenemos que examinar sus raíces y su naturaleza" (Arendt, 1970, capítulo 2, párrafo 25).

Siguiendo una lógica reactiva ante la normalización impuesta por la cultura, es posible que de mano de la violencia no todo sea destrucción. Si la cultura es una forma de sumisión, como dice Sloterdijk, la violencia puede ser una forma de rebeldía, de emancipación, de ahí su concebible perspectiva moral o la posibilidad de construir algo de su mano, y de ahí, sin duda, su poderosa capacidad de fascinación. La cuestión es cuando la contemplación de la violencia no es más que un fin en sí mismo, despojada de su posible efecto instrumental, su valor se limita al escaso componente catártico que aún pueda aportar a unos ojos agotados de mirar. Esta vez es Susan Sontag la que nos aporta su reflexión final: "Saturados de imágenes de una especie que antaño solía impresionar y concitar la indignación, estamos perdiendo nuestra capacidad reactiva. La compasión, extendida hasta sus límites, se está adormeciendo" (Sontag, 2003, capítulo 7, párrafo 10). ¿Estamos de acuerdo? Hace tiempo que entramos en la zona de peligro, donde un espectador indignado pasa a ser un espectador fascinado que, como el bombero pirómano, no puede evitar caer bajo el hechizo visual del espectáculo que debería combatir.

\section{Notas}

${ }^{1}$ Mary McCarthy, importante novelista y ensayista americana, amiga íntima de Hannah Arendt, a quien Arendt le dedica su libro Sobre la violencia.

${ }^{2}$ Eichmann, por cierto, fue también responsable del falso documental idílico del campo de concentración de Theresienstadt o Terezín, una vuelta de tuerca al concepto de violencia como espectáculo, en este caso el de la violencia oculta como espectáculo de poder, un ejercicio de maquillaje y disimulo de la miseria moral, que convierte la Solución Final en algo aún más deplorable si cabe en términos éticos, ya que revela la actitud vergonzante última de sus propios ideólogos. 


\section{JUAN CARLOS PÉREZ JIMÉNEZ}

${ }^{3}$ Expansión, 30-11-04, p. 40.

${ }^{4}$ En el siglo III, el persa Manes o Mani, de quien deriva el concepto de maniqueísmo, concibió esta doctrina dualista que se define por la lucha de dos principios enfrentados, la luz y las tinieblas, sin términos medios.

${ }^{5}$ Peter Sloterdijk, Die Zeit, 21 de agosto, 2015.

\section{Referencias}

Antonelli, P., \& Hunt, J. (2015). Design and Violence. Nueva York, United States: MoMA.

Canogar, D. (1993). La realidad virtual y la sociedad del espectáculo. Plusvalías de la imagen. Bilbao, España: Rekalde.

Dieckmann, H. (1985). Psychological Reflections on the Nuclear Threat. Quadrant, 18 (2), 57-70.

Freud, S. (1987a). El malestar en la cultura. En Obras completas: Sigmund Freud (pp. 3017-3067). Madrid, España: Biblioteca Nueva.

Freud, S. (1987b). El porqué de la guerra. En Obras completas: Sigmund Freud (pp. 32073215). Madrid, España: Biblioteca Nueva.

García, M. Ruiz, J. (2004). Violencia y medios de comunicación. El impacto de la violencia televisiva en la infancia de la Comunidad de Madrid. Madrid, España: Centro Universitario Villanueva.

Jones, J. (2002). Matando monstruos. Por qué los niños necesitan fantasía, súper-héroes y violencia imaginaria. Barcelona, España: Ares y Mares/ Editorial Crítica.

Lacan, J. (2010). ¿Qué es un cuadro? En Seminario 11. Los cuatro conceptos fundamentales del psicoanálisis (pp. 112-126). Buenos Aires, Argentina: Paidós

Lacan, J. (2013a). La agresividad en psicoanálisis. En Escritos 1 (pp. 107-128). Madrid, España: Biblioteca Nueva.

Lacan, J (2013b). El estadio del espejo como formador de la función del yo (je) tal como se nos revela en la experiencia psicoanalítica. En Escritos 1 (pp. 99-106). Madrid, España: Biblioteca Nueva.

Serrano, V. (2018). Fraudebook, lo que la red social hace con nuestras vida. Madrid España: Plaza y Valdés. 


\section{REVISTA STVLTIFERA DE HUMANIDADES Y CIENCIAS SOCIALES}

VOLUMEN 1, NÚMERO 1, PRIMER SEMESTRE DEL 2018

ISSN 0719-983X

\section{Artículos de Humanidades y Ciencias Sociales}

La violencia como espectáculo.

Juan Carlos Pérez Jiménez

El amo castrado.

Elisa Freijo Corbeira

España, una meditación política: Cataluña y Euskadi.

Mikel Aramburu Zudaire

Del saber sabio al saber dramatizado. Nuevos fundamentos para la aplicación permanente del teatro en el aula.

Luis Fernando Lara Coronado

Ontotecnia, ingeniería organizacional y actores emergentes.

Alejandro Ochoa Arias y Juan Antonio González de Requena Farré

\section{Reseñas}

Memoria Visual de Legua Emergencia, vida y oficio de Mario Alarcón.

Pedro Pablo Achondo Moya

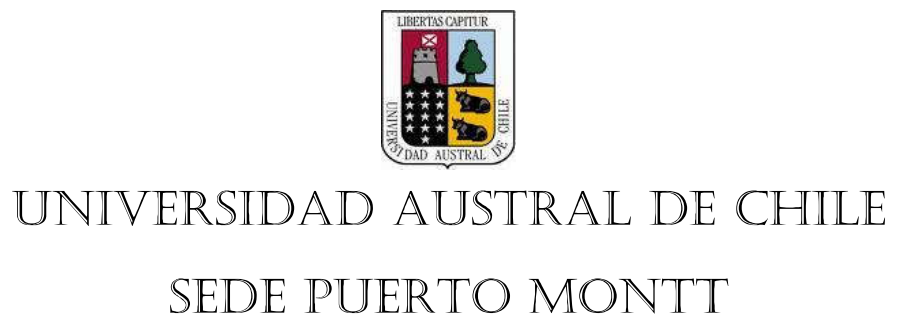

